\title{
Ukrainian National Dumas: National Perceptions in the Process of Intercultural Communication
}

\section{Українські народні думи: національні особливості сприйняття в процесі міжкультурного спілкування}

\author{
Maryna Nabok \\ Ph.D. in Philology, \\ Associate Professor
}

\author{
Марина Набок \\ кандидат філологічних наук, \\ доцент
}

E-mail: $\underline{\text { nabok.marinka@gmail.com }}$
orcid.org/0000-0001-9422-730X

Sumy State University,

2, Rimsky-Korsakov Str.,

Sumy, Ukraine, 4000
Сумський державний університет,

$\square$ вул. Римського-Корсакова, 2, м. Суми, Україна, 40000

Original manuscript received March 26, 2018

Revised manuscript accepted October 01, 2018

\begin{abstract}
The article presents the results of empirical research on ethnopsychological groups of people living in different regions of Ukraine in the context of intercultural ideological systems. In particular, residents of Ukraine and foreign students from Africa and Middle East, which study at Sumy State University, were invited to share their impressions from the listened dumas, performed by Canadian bandurist Victor Mishalow during his concert tour in Ukraine. They also watched and listened to video recordings of such folk dumas as "Cossack Golota", "Marusya Boguslavka» performed by kobzar Mykola Budnyk and bandura player Fedir Zharko. Students analyzed the characters' images, expressed their understanding and attitude to characters' actions and compared them with the national heroes of their own countries.

The national peculiarities of the worldview of Ukrainians, representatives of Africa and the Middle East expressed in their language are defined. The language itself is the core of people's psyche, way of thinking, and identity of ethnic group's moral and ethical norms of life. The analysis of folk art helps
\end{abstract}


to emphasize the peculiarity of foreign students' perception of words, rhythm, music, and the symbolic system of folk poetic works. Author notes that the psychological of figurative system of Ukrainian dumas and folk songs of the mentioned peoples has a purely national color: it is a category of national outlook and at the same time is a artistic and aesthetic category.

The solution of these problems forms an understanding of the specific of national characters and the national world in folk poetic works of the peoples of Africa, the Middle East and Ukrainian folk dumas, which is the main purpose of the study and its novelty, because such typological comparisons are investigated for the first time.

These experimental studies, the development of the ideas of dumas studies and studies on a national character, the peculiarities of a national world perception, world outlook and world expression have substantiated the need for a deeper study of Ukrainian dumas' role in the formation of the national personality during intercultural communication.

Key words: duma, ethnopsychology, national peculiarities of perception, world outlook, intercultural communication, national character, folk art.

\section{Вступ}

Стрімкий ріст різних форм i способів міжкультурного спілкування сьогодні вимагає вивчення і осмислення особливостей національного світосприйняття, світорозуміння, світовираження i світоствердження того чи іншого народу. Важливість даного підходу до організації такого спілкування полягає, насамперед, у розумінні «свого» крізь призму «чужого» і «чужого» крізь призму «свого». У такому разі, з одного боку, ми уникаємо досить часто безпідставних, ненаукових тверджень про, так звані, впливи на основі подібності явищ різних культур там, де таких впливів зовсім немає, 3 другого ж, досягаємо рівноправності учасників такого спілкування, їх зацікавленості в обміні культурними цінностями, a відтак i ïx світоглядного взаєвпливу в процесі формування духовного світу та висококультурної особистості в цілому.

Mema cmammi полягає у теоретичному та емпіричному вивченні світоглядного потенціалу українських народних дум, психологічних особливостей їх сприйняття, розуміння та потрактування в процесі міжкультурного спілкування. Українські народні думи у світоглядному, духовному та художньо-естетичному виявах становлять хоч і цікаве, але досить складне явище. Саме 
тому основними завданнями статті ми вважаємо 1) теоретичний аналіз українських народних дум як вияву праукраїнських та українських уявлень про людину і світ; 2) емпіричне вивчення специфіки та характеру сприймання дум студентами-іноземцями 3 метою значно глибшого розуміння ними їх змісту; 3) окреслення подальшої перспективи вивчення виховних можливостей українських народних дум з метою впровадження їх у педагогічну практику та міжкультурне спілкування.

У науковій та науково-методичній літературі, присвяченій розв'язанню цієї проблеми, увага вчених зосереджується, головно, на контактному, генетичному та типологічному аспектах. Так, у дослідженні «У колі світової культури» (2006), Г. Нудьга подає багату, досі невідому чи то маловідому, інформацію про поширення, сприйняття, розуміння i виховну функцію творів українського народного епосу та лірики серед народів Європи, Азії, Америки, Австралії та Африки. Розширюється й географія таких досліджень. Скажімо, предметом уваги С. Наливайка (Наливайко, 2000, 2004, 2007) стали українсько-ірансько-індійські етнічні, мовні, історичні, міфологічні, фольклорні та культурні зв’язки. Важливим підгрунтям дослідження національних особливостей світовідчуття, світосприйняття, світорозуміння, виражених у народнопоетичній творчості, є й праця О. Потебні «Думка і мова» (1892). Ідеї та положення цих та інших праць ми продовжили i розвивали в Сумському державному університеті в процесі вивчення особливостей сприйняття українських народних дум студентами 3 країн Близького Сходу та африканських країн, що ще не було предметом спеціальних наукових досліджень. Добре прислужилися нам і праці зарубіжних учених, на які покликаємося в статті.

\section{Методи та методики дослідження}

Для розв'язання поставлених завдань було використано комплекс методів дослідження. Теоретичні: теоретичний аналіз, синтез, абстрагування, порівняння, узагальнення, систематизація; емпіричні: анкетування, бесіда. Зокрема, іноземні студенти проаналізували образи головних персонажів українських народних дум «Козак Голота», «Маруся Богуславка», поетику, естетику народнопоетичних творів. У процесі аналізу структурно-генетичний чинник відіграв важливу роль у сприйнятті цілісності художніх 
образів. Дослідження проводилося зі студентами старших курсів, які на достатньому рівні володіють російською та українською мовами. Загальна кількість - 56 опитаних іноземних студентів (вік 22-26 років) та 147 жителів (середній та похилий вік) з різних сіл та міст України. Прослухавши думи, слухачі написали відгуки, висловили своє ставлення до зображеного, порівняли козака Голоту та Марусю Богуславку 3 національними героями своїх народних пісень.

У процесі міжкультурного взаємообміну виявляємо своєрідність світосприйняття і світорозуміння кожного окремого народу. Студенти з Африки, наприклад, на відміну від студентів 3 Близького Сходу, по-різному сприйняли образи козака Голоти та Марусі Богуславки. В процесі міжетнічної взаємодії, узагальнюючи та систематизуючи написане у відгуках, підкреслюємо в слухача морально-етичні, етнопсихологічні особливості його внутрішнього «Я», сформовані на національному грунті, а це спонукає до подальших емпіричних досліджень задля впровадження в педагогічну практику етнопсихологічних, психолінгводидактичних аспектів у вивченні мов, досягнення взаєморозуміння між представниками різних народів та недопущення насильства в сучасному світі. Зазначимо, що на сьогодні питанню впливу національної ідентичності в кризових комунікаціях присвячується все більше і більше досліджень західно-єропейських вчених (Borden, 2016; Kim \& Sung, 2013 та ін.).

\section{Результати та дискусії}

У кожного народу філософія споглядання, відображення світу і себе в ньому мала своєрідний характер, сформаний упродовж свого історичного розвитку та відтворений в народних міфах, легендах, усній народній творчості загалом. Так, наприклад, в міфах, легендах народів світу відтворена пізнавальна діяльність людини, де конкретний предмет мав свій зміст, логіку та потім ставав символом. Тож, не окремі ритуали трактувалися як архетипи певних сюжетів та жанрів, а ритуально-міфологічні світоглядні типи, які трансформувалися в різні сюжети і жанри на основі властивих їм своєрідних ознак. Зокрема, в українських народних думах, колективна фантазія змінюється на індивідуальну, більш земну, впорядковану і осмислену. Архетип в думах - це вже «комплекс 
внутрішніх переживань, що породжує ідеї» (Сліпушко, 2001: 144). Архетипна ідея волі, наприклад, реалізується в образі коня, сокола i т. п. Індивідуально-авторське бачення картини світу в думах уособлено в образі оповідача, творця і виконавця думи. В його епічному виконавстві закладені глибокі «програмні» настанови, що «спираються не на швидкоплинну емоційну реакцію слухача дум, а на тривале образне іï осмислення» (Черемський, 2002). Виконуючи народну думу, кобзар крізь призму серця, що $\epsilon$ безпосереднім провідником власних почуттів та переживань, долучає слухачів до співпереживання за долю героїв дум, таким чином ненав'язливо спонукає їх доторкнутися до «духу», «душі народу». Важливим за цього залишається ще не достатньо вивчене у виконавстві дум питання взаємодії мови, рухів тіла, мультимодальних ресурсів, що характеризуються сприйняттям інформації в письмовій (візуальній) та звуковій (слуховій) формах (Thorne, 2016). У контексті міжкультурних світоглядних систем, розглянемо сприйняття народних дум вже сучасними слухачами. Зокрема, жителям різних регіонів України та чужоземним студентам було запропоновано поділитися враженнями від прослуханих дум у виконанні бандуриста австралійсько-українського походження Віктора Мішалова, який нині мешкає в Канаді і в липні 2010 року здійснив концертну подорож по Україні. Вони переглянули та прослухали відеоаудіозаписи народних дум «Козак Голота», «Маруся Богуславка», проаналізували образи героїв, висловили своє розуміння і ставлення до їх дій і вчинків, зіставили з героями уснопоетичних творів своїх країн. Зазначимо, що сприйняття художнього тексту, в тому числі і його психолінгвістичний аналіз, характеризується сукупністю оцінок читачів та слухачів, зумовлених «комплексом соціально-психологічних і мовно-культурних причин» (Сорокін, 1985: 16). Тож, після прочитання думи «Козак Голота» та прослуховування аудіозапису у виконанні бандуриста Ф. Жарка переважній більшості студентів 3 Африки козак Голота уявлявся людиною на коні. Для студентів з Близького Сходу герой думи це захисник своєї Батьківщини. Читаючи думу «Козак Голота», іноземні студенти не завжди розуміли, чому це «на козакові шапкабирка / Зверху дірка / Травою пошита / Вітромъ підбита / Куди віе, туди й провівае / Козака молодого прохоложае» (Українські народні думи, 1931: 9). Так виникла необхідність пояснити прочитане 
i, головне, наголосити на поетичності, образності мови твору. «Розшифровуючи» поетичні формули цієї думи, студенти були вражені силою, багатством української мови та природним, тонким вчуттям українців у навколишній світ. Після пояснення вони легко зрозуміли, чому козак був бідно одягнений і не прагнув дорогого вбрання татарина, бо ж багатство не було прикметною ознакою козака-лицаря, який вільно гуляє степами, у боях з ворогами, у повсякденному житті виявляє лицарські чесноти.

Таким чином, через механізм вербального сприйняття, а саме, через впізнання, як рецептивну дію, та усвідомлення зв'язків між семантичними одиницями тексту, в іноземців виникла смислова єдність образу. Відтак, слово «козак» у свідомості студентів 3 Африки набуло глибшого значення: це вже не просто людина на коні, а людина з багатим внутрішнім світом. У процесі вербального та невербального спілкування, студенти з Африки зрозуміли не лише героїчний характер козака Голоти, але й тонко відчули його зв'язок $з$ навколишнім світом. Для них стало зрозумілим, чому козак Голота звертався до поля Килиїмського як до живої істоти, подібної собі, адже розуміння краси в українців вбачалося не лише у «ясних зорях» і «тихих водах», а й у злитті людини з природою. Таке світосприйняття і світорозуміння відображено в первісній релігії праукраїнців, коли людина i природа усвідомлювалися як єдине ціле.

У процесі сприйняття думи, увага студентів з країн Африки була зосереджена на словах з голосними звуками. На це вплинула манера виконання кобзарем думи, коли в ритмізованому співі інтонаційно подовжувалися, повторювалися, вигукувалися голосні звуки, а це дало поштовх до відтворення в пам'яті англомовних студентів чогось подібного, знайомого в їх мові. Наприклад, в українській мові 6 голосних звуків. В англійській мові теж 6 голосних звуків, які промовляються з відкритим ротом і їх можна проспівати. Проте в англійській є довгі і (long vowels) та короткі (shot vowels) голосні. Довгих голосних п'ять, коротких - один. Крім цього, є ще й вісім дифтонгів - поєднання двох голосних звуків в одному складі. Тож, таке розуміння студентами-африканцями образу героя пояснюємо не лише специфікою їх національного характеру, але й спільністю деяких мовно-фонетичних складових англійської та української мов. За цього в пізнавальній уяві іноземця-слухача 
Українські народні думи: націіональні особливості сприйняття...

образ героя думи набуває яскравого відтінку: козак в доброму настрої, гуляє полем, впевнений у своїй перемозі над ворогом, бо він сильний, розумний. Таким чином, мова - це не лише відображення культури народу, але і його психології. В такому взаємозв'язку психіки та мови в реципієнта на основі вже знайомого, підсвідомо формується асоціативний зв'язок, звукосимвол, зумовлений етнічними особливостями його світосприйняття і світорозуміння.

Образ козака Голоти, концепт «людина і природа» студенти 3 Близького Сходу сприймають в площині його відданості своїй землі, за яку він бореться. Так, наприклад, Абдерахім (Туреччина, 916 гр.) зазначає: «Головне для козака - це бути вільним. Коли козак Голота воює і отримує перемогу, то для нього це почесна справа. Тоді й прославляє він не лише себе, свої дії, але й поле, де вони отримали перемогу» (архів автора). Звернімо увагу, як студент об'єднав у єдине ціле людину і поле, на якому козак Голота отримав перемогу. Для нього дії героя думи не $\epsilon$ одноосібними. Курд Ридван (Туреччина, 916 гр.), також зазначає, що головним для героя думи є відчуття єдності із землею. «Земля допомогла козакові тільки тому, - пише він у відгуку, - що цей лицар народився на цій землі, ріс і увібрав іiі силу, що й стало джерелом його перемоги» (архів автора).

Студентів з Іраку в українських народних думах теж захоплює героїчна боротьба та смерть козака за рідну землю, що є особливо близьким і зрозумілим для них, адже викликає своєрідні роздуми над своєю долею та долею свого народу. Так, наприклад, студент четвертого курсу Рифаат (Ірак, 913 гр.) засвідчує: «Я завжди готовий вмерти за Батьківщину, тому я буду жити вічно. Це моя земля, мої люди. За все це я віддаю душу. Аллах мене створив, і може взяти мою душу, коли потрібно. Ми будемо жити!...» (архів автора). Тобто, Рифаат бачить в українських козаках-лицарях своїх однодумців, глибоко розуміє їх прагнення і поривання до свободи. Важливу роль в процесі такого сприйняття думи студентами 3 Близького Сходу відіграє образ виконавця думи, бо саме завдяки його вербальному та невербальному діалогу зі своїм слухачем, він скеровує його ментальну діяльність до сприйняття індивідуальноавторської картини світу, в якій герой думи постає як символ нації, надлюдина. Його «філософія серця», «філософія життя» глибоко закорінені в основи національного характеру, психології, етики, 
естетики. На структурно-семантичному рівні, студенти з Близького Сходу, на відміну від африканських, звертають увагу на дієслівні конструкції: козак Голота гуляє, ні села, ні города не займає, на город Килію поглядає, до татарина промовляє, хоче живцем у руки взяти та ін. Це зумовлено особливостями їх національного психотипу: вони жваві, рухливі, постійно потребують уваги, допитливі, і щоб знайти відповідь на питання, постійно в пошуку. Прикладом може бути їх народна творчість. Так, наприклад, в курдській народній пісні «Bêrîtana» («Берітана»), головним героєм $є$ молода дівчина. Вона постає в образі лева «şer», очолює і веде за собою військо. У різних варіантах цієї пісні образ лева змінюється на образ хвилі «pêlan», яка грізно нищить все довкола. В цій народній пісні теж переважають дієслова на позначення руху. Герой арабської народної пісні 《وديه ثيصد («Заповідь мученика»), подібний козакові Голоті, бо ж так само сміливий, активний, звертається до сил природи за допомогою. В такому разі можемо говорити про первісні світоглядні уявлення (фетишизм, анімізм) у фольклорі арабських народів. Так, наприклад, дерева, ріки разом із героєм переживають

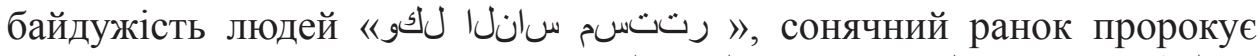
щасливий, переможний день رارظلا امودحي العلا وحن ياقاس (ر), а небо, як рай, огортає його душу і сповнює легкістю. Як зауважує Сайф Хдаір (Палестина, 331 гр.), за релігійними арабськими віруваннями, душа людини продовжує жити вічно саме на Небі. Це своєрідне воскресіння через вмирання (Маслова, 2018: 170). Відтак, світосприйняття сучасного молодого арабського покоління засноване на глибинній генетичній памяті, в основі якої давні архетипні уявлення про циклічність людського буття. Семіотика слів дерева, ріки, небо, виражена бінарними опозиціями архетипно-морфологічного аспекту (Слово Космос), релігійно-філософского аспекту (Слово - Бог / Буття), психологічного аспекту (Слово - Мислення / Душа), естетичного аспекту (Слово - Краса), створюють особливу художню концепцію світотворення.

В українській символіці небо уособлено в образах Сонця, Місяця, Зірок. Для українців уявлення про сонце - це втілення морально-етичного ідеалу, до якого слід прагнути, воно є активним психічним фактором, здатним викликати процес самоідентифікації. Роль сонця полягала у забезпеченнні самого буття людини через 
тепло і світло; сонце дає людині духовно-моральні орієнтири (світло свідомості), формує уявлення про сенс життя, сприяє психологічній ініціації особистості. Тож, символ сонця у фольклорі українців є постійним нагадуванням людині про те, що в іiї душі є світло добра, подібне до сонячного світла. Образ місяця українці пов'язували 3 темними, злими силами через його здатність періодичної втрати яскравості. Але місяць сприймався не як покровитель сил зла, а навпаки - він «не пропускав» зло у світ людей.

В арабському фольклорі Небо уособлює світлу енергетику, яка має надзвичайну силу, бо саме до нього відходили душі відважних воїнів. Герої в арабській народній пісні 《وديص شي («Заповідь

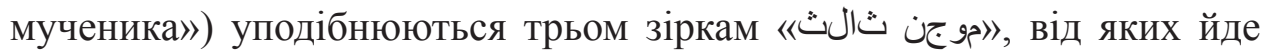

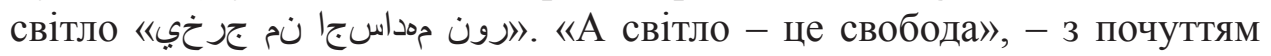
гордості пояснює далі Сайф Хдаір. В народній уяві праукраїнців саме на зірки проектувалися психологічні якості людини, що спонукало її до вибору між добром і злом. В арабських віруваннях зірки - це помічники. Халід Абусамра 3 Палестини (331гр.) пояснює, що існує особлива зірка на ім’я Сурая 《نج حزايرثل

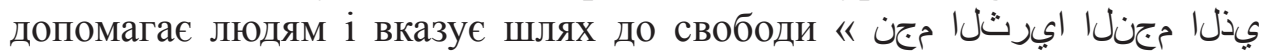
(قيرطلا علا عار حصلا يف سانلا داشر ا يف دعاس (архів автора). Аллах створив світ, у якому співіснують добро і зло, ангели і демони. Тому зірки в уявленнях арабських народів символізують воїнів, які не допускають нечистим силам піднятися до неба та нашкодити Богові, адже злі сили не повинні слухати та вивідувати плани Аллаха. Тож, спільним для українського та арабського світосприйняття $\epsilon$ те, що саме ці космообрази є сильними енергетично, вони завжди випромінюють світло життя, допомагають людині. Таким чином, емпірично було зафіксовано когнітивний процес впізнання «свого» через «чуже». Відтак, слова-символи Небо, Сониее, Місящь, Зірки є своєрідними генетичними макроформулами, які несуть в собі комплексну інформацію про зміст слова, його «родовід». У цьому контексті М. Маковський в «Лінгвістичній генетиці...» зазначав: «Будь-яка лексема - це своєрідний мікросвіт людини, що увібрав у себе весь комплекс складних i багатовимірних генетичних перетворень, що передували його становленню. Вона тисячами невидимих ниток і переходів співвіднесена 3 макросвітом мови, 3 певним комбінаторно-генетичним середовищем. Таким чином, слово є безцінним сховищем, потенційним згустком своїх 
Ukrainian National Dumas: National Perceptions in the Process...

генетичних можливостей, що безпосередньо походять 3 його історії» (Маковский, 2007: 105). Тож дихотомія «мова - культура» та трихотомія «мова - свідомість - культура» взаємодоповнюють один одного (Сорокін, 1994: 15). Саме людська свідомість відіграє роль посередника між культурою й мовою. У свідомість надходить культурна інформація, де вона переробляється, систематизується та «входить» у фольклорний, художній текст, комунікативну ситуацію, що й зауважуємо у відгуках чужоземних студентів.

Мешканці міста Переяслав-Хмельницький народні думи сприймають якось тривожно, по-філософськи і разом 3 тим велично, адже кожен слухач у виразних рецитаціях В. Мішалова душею i серцем відчуває незламність духу нації і це не випадково. Саме тут у 1750-х роках у Переяславському колегіумі учителював Григорій Сковорода, у 1845 та 1859 роках у свого переяславського друга Андрія Козачковського жив Т. Шевченко та написав «Заповіт», «Наймичку», «Кавказ» і вступ до поеми «Єретик», в 30-х роках 19 ст. деякий час жив Микола Гоголь. Гордістю міста є єдиний у світі музей українського кобзарства, відкритий 4 березня 1989 року. Тож прикметно, що в прослуханих думах жителі ПереяславХмельницького відчули зв'язок з героїчним минулим, спрямованість змісту дум у наше сьогодення, адже й «сьогодні нерідко панує черствість, пихатість, цинізм і зверхність у ставленні до рідних та близьких людей, що розколює родини, суспільство, знецінює сімейні цінності, стає причиною багатьох наших бід. А дума зворушує. Дума застерігає. Дума учить, спонукає думати», - коментує житель міста Олександр Юрченко.

Прослухавши українські народні думи «Козак Голота» та «Маруся Богуславка» у виконанні В. Мішалова, пенсіонерка Ганна Дмитренко із села Семенівка Липоводолинського району Сумської області зазначила, що все почуте якось глибоко запало їй в душу, тривожило їі «...бо то усе наше, старовинне. Ним жили наші і діди, i прадіди, i прапрадіди. А тепер? Один телевізор, бари та якісь дискотеки» (Вертій, 2013: 31).

Після виступу В. Мішалова, директор Гадяцького районного Будинку культури Віктор Жартовський поділився своїми думками від почутого і пережитого. «Щось неймовірне! - говорить він. На концерті В. Мішалова живеш у якомусь зовсім іншому, хоч i незнаному досі, але такому до болю рідному світі. Від того щемно 
стає на серці: чому наше, рідне, дороге так довго залишалося чужим для нас? Вражає техніка виконання, колорит виконаних творів. Обидві руки не просто перебирають струни. Вони викликають 3 них муки, болі, радощі і страждання. Візьмемо для прикладу ту ж таки думу «Маруся Богуславка». Гармонія тут у всьому: своє, особисте (героїв твору, виконавця і слухача) і народне не існують самі по собі, вони самовиражаються одне в одному, творять єдиний світ (Вертій, 2013: 23).

Природно, що жителі міст України в образі козака Голоти, Марусі Богуславки відчули щось близьке їх внутрішньому світу. Так, наприклад, піднесений, урочистий тон виконання кобзарем думи «Козак Голота», інтонаційні наголоси на лексичних синтаксичних одиницях як «Ой полемъ, полемъ Килиімськимъ, / То шляхомъ битимъ Гординськимъ, / Ой тамъ гулявъ козакъ Голота. / Не боітия ні огня, ні меча, ні третёго болота» (Українські народні думи, 1931: 9) розкривають характер внутрішнього «Я» героя думи як суб'єкта життєтворення, світ якого близький слухачам думи. Твори, в основі яких лежить опис навколишнього та внутрішнього світу «Я» героя, В. Белянін називає «світлими» текстами (Белянін, 2000: 72). За цього, психологічна модель сприйняття такого часопростору в думі втілена у лексичних метаобразах «Поле - Шлях - Дім / Україна». У них оповідач, творець і виконавець думи втілив життєствердну картину світу i героя в цьому світі, для якого свобода є основою його дій та вчинків. Прикметно, що ці метаобрази отримують додаткові семантичні, психологічні складові засобом художньої поляризації образу козака Голоти: перебуваючи у природному для козака середовищі («Поле Шлях - Дім / Україна») в емоційно-піднесеному стані переможця, який нікого i ніщо не боїться, його одяг виглядає бідно - «шати дорогиі - / Три семирязі лихиі: / Одна недобра, друга негожа, А третя й на хлів незгожа. / А ще правда, на козакові постоли вязові, / А унучи китайчані - Щирі жіноцькі рядняні; / Волоки шовкові - / Удвое жіноцькі щирі валові» (Українські народні думи, 1931: 9). Таким чином, провідний семантичний компонент «не боітия ні огня, ні меча, ні третёго болота» доповнюється новими мовними одиницями шати лихї, недобра, незгожа, унучі жіночі ряднані. Подібні слова таких «світлих текстів» (за В. Беляніним) ми називаємо психологічними синонімами, адже 
вони, незалежно від їх загальномовної несинонімічності, передають загальний психологічний стан героя, який впливає й на слухацьку аудиторію. Таке символічне слововираження пробуджує в уяві традиційного слухача архетипну пам'ять, архетипні образи, сюжети, воскресіння героїв. Важливу роль в цьому відіграє оповідач, творець і виконавець дум, уснопоетична мова якого була насичена давніми українськими лексичними одиницями, лінгвопоетичними формулами, художніми образами, які на підсвідомому рівні спонукали слухача до «віртуального контакту людини з оспіваними образами, під час якого людина шукала i знаходила відповіді на нагальні питання, які конче мусила для себе вирішити. Зі слухача знімався психотравматичний тягар, відбувалося ніби катарсичне очищення людини й наснаження до подальшого активного життя» (Черемський, 2017: 187).

Чужоземні студенти образи героїв дум сприймають в площині диспозиції «своє - чуже». Вони, наприклад, з розумінням та повагою ставляться до героїні думи «Маруся Богуславка», адже вона чітко кладе межу між «своїм» та «чужим». Слухаючи виконання думи кобзарем, вони усвідомлюють, що козаки-невільники для Марусі Богуславки $\epsilon$ «своїми». Образ Марусі Богуславки африканські студенти сприймають як своєрідний образ-переживання, що $\epsilon$ типовою картиною духовного світу людини 3 теплих країн, де під впливом кліматичних умов (i не тільки), формувалося тонке відчуття людиною навколишнього світу. Тому вони співпереживають як невільникам, які «тридцять літь у неволі пробувають / Божого світу, сонця праведного у вічи собі не видають» (Українські народні думи, 1927: 24), так і Марусі Богуславці, яка «до темниці прихожае, Темницю відмикае / Всіхъ козаків / Біднихъ невольників / На волю випускае» (Українські народні думи, 1927: 24). Студенти 3 Близького Сходу сприймають образ Марусі Богуславки в іншій площині. Їх увага зосереджена на іï діях, а саме, на звільненні своїх земляків й тому, що вона не втекла разом із невільниками. Такий вчинок українки студенти пояснюють їі мудрістю і далекоглядністю. Наприклад, курд Абдерахім (Туреччина, 916 гр.) зазначає: «Дуже добре вона зробила, що відпустила земляків. А що не пішла 3 ними, теж добре. Коли б втекла 3 козаками, то султан обов'язково їx наздогнав би i знищив усіх. Та оскільки вона залишилася, то була вірогідність того, що він цей вчинок їй пробачить. Таким 
чином козаки успішно дістануться на рідну землю» (архів автора). Гьокальп Кайяпинар (Туреччина, 427 гр.), аналізуючи образ Марусі, зауважує, що жінка для чоловіка-турка має належати тільки йому, він ніколи не допустить зради. I якщо б Маруся втекла від султана, то смерть для неї була б неминучою. «Зрадила його - то зрадила все навколо себе» (архів автора). Розуміння поняття «кохання» в турецькій мові відтворено в лексемах як почуття aşk (кохання $\rightarrow$ epoc), sevda (кохання $\rightarrow$ часто символізує нерозділене кохання), sevgi (кохання $\rightarrow$ симпатія), ruh (душа), gönül (серце / душа) i kalp (сердце $\rightarrow$ у фізіологічному значенні) (Айдин, 2014: 7). В турецькому менталітеті, за словами Алі Айдина, переважає конотація «лікування/зцілення/вивільнення від страждань та суму» (Айдин, 2014: 7). Якщо увагу студента з Туреччини привертає образ Марусі Богуславки як мудрої, відданої жінки своєму султанові, яка заспокоює його серце, лікує душу, звільняє від страждань, то Мухаммад Абу Хамеда (310 гр.) з Йорданії захоплений іiі сміливим вчинком. Для нього вона $є$ прикладом для наслідування. «У нас в Йорданії - зауважує студент, - в піснях возвеличуються образи короля, генерала, керівника, але ніяк не простих, звичайних людей. Українці ж бережуть в пам'яті подвиги славних козаків, возвеличують їх у піснях. Хоробрими $є$ не тільки чоловіки, але й дівчата» (архів автора). Аналізуючи народну думу, студент робить висновок про те, що цей народний твір потрібно вивчати у школі. Зазначимо, що в освітній системі США вже багато років запроваджена інтеграція мистецтва в навчальний процес, що дозволяє виховувати в учнів та студентів креативність, творче мислення (Dowell \& Goering, 2018: 85-91). Цікавим є зіставлення цих міркувань студента 3 Йорданії зі сприйняттям та враженнями українського слухача.

Таким чином, проведене нами емпіричне дослідження на основі відгуків студентів 3 країн Африки, Близького Сходу та жителів різних регіонів України потребує певних висновків та узагальнень. Сприйняття українських народних дум кожного слухача i читача засноване на тісному взаємозв'язку національних основ світосприйняття, світорозуміння та світоствердження. Образи героїв дум козака Голоти та Марусі Богуславки студенти з Африки на 80\% сприймають як образ-переживання, що стає типовою картиною їх духовного світу. Вони співпереживають за долю дівчини, яку 
татари забрали в неволю, невільникам, які перебувають в темниці, козаку Голоті, який бідно одягнений. Лише $20 \%$ студентівафриканців сприйняли козака як людину на коні. Етнопсихологічні особливості характеру таких студентів засновані на виокремленні 3 синтаксичного ряду голосних звуків, звукосимволів, які у поєднанні зі співогрою створюють своєрідні для них художні образи. За цього, козак Голота вже сприймається не просто людиною, яка бідно одягнена та гуляє полем, а як героя-захисника цього поля та України в цілому.

Майже 100\% опитаних студентів 3 країн Близького Сходу сприймають образи головних героїв як захисників своєї землі. Колективне несвідоме засноване на розумінні свободи, як життєдайної космічної енергії, яка пов'язує покоління на віки. Образ Марусі Богуславки для них є втіленням мужності (вона звільняє «своїх» 3 «чужого» простору задля продовження боротьби за свободу), для студентів з Туреччини - прикладом сильної жінки, яка віддана султанові. Тільки чотири арабських студентів не зрозуміли зміст дум, але манера виконання, музичний супровід дум дозволили їм виокремити урочисто-піднесений тон у зображенні образу козака Голоти та емоційно-чуттєвий у виспіві образу Марусі Богуславки.

У цьому контексті варто наголосити на результатах досліджень І. Бубнової та О. Казаченко, які аналізували смислове значення слова «свобода» для молодого покоління Росії. Переважна більшість молодих людей віком від 17 до 25 років сприймають свободу як звільнення від обов'язків, відповідальності за вчинки, що «дозволяє здійснювати найбільш небезпечні вчинки, якими сьогодні перенасичене наше життя. I збільшення кількості людей, які сприймають свободу як повне ігнорування суспільства, загрожує існуванню суспільства як такого» (Бубнова \& Казаченко, 2018: 20). Як бачимо, наші результати дослідження у сприйнятті та розумінні слова «свобода» молодими людьми 3 Близького Сходу прямо протилежні. Живучи за тисячі кілометрів від дому, вони не втратили зв'язок з Родом, у їх свідомості закладений генетичний код нації, релігійно-філософський погляд на буття, де Свобода $є$ найбільшою цінністю. За словами Ю. Сорокіна, це своєрідна культу рема / менталема циркулює у всередині певної лінгвокультурної спільноти, яка характеризується гомогенністю, стабільністю та 
Українські народні думи: націіональні особливості сприйняття...

дозволяє зберігати унікальність і цілісність (Сорокін, 1994: 94). За результатами нашого емпіричного дослідження, такою спільнотою є арабська.

Серед 145 мешканців сіл і міст України, які прийшли на концерти В. Мішалова відгуки дали 19\%. Образи козака Голоти, Марусі Богуславки, Поля, Шляху та ін. вони сприймають підсвідомо, що пробуджує генетичну пам'ять, яка спала довгі роки і яку в різні способи викорінювали із свідомості українців. Тому в подальшому нам потрібно пропагувати вивчення дум у школах, університетах, ознайомлювати світ $з$ нашим унікальним культурним надбанням.

\section{Висновки}

Національні особливості сприйняття українських народних дум у процесі міжнаціонального спілкування значною мірою, як бачимо, залежать від своєрідностей світосприйняття, світорозуміння, світовираження, світоствердження того чи іншого народу чи то окремих його представників. Усна народна творчість кожного окремого народу $\epsilon$ важливим джерелом у дослідженні їх національних картин світу, що грунтується на суто національному розумінні основ народної моралі, етики, естетики. Це дає можливість у багатокультурному мовному середовищі краще зрозуміти один одного та входити в життя сучасного світу на своїх питомо національних духовних підставах.

Пізнання «свого» крізь призму «чужого» і навпаки - «чужого» крізь призму «свого», зближує народи, збагачує взаємообмін духовними цінностями, які стають джерелом формування почуття національної гордості, духовно багатої, високорозвиненої особистості, високої культури міжнаціонального спілкування, що й стає вагомим внеском в удосконалення всієї системи навчальновиховної роботи у середній та вищій школі, у впровадження етнопсихологічних, психолінгводидактичних аспектів у вивченні мов та у взаєморозуміння та духовне взаємозбагачення народів загалом.

\section{Література}

Айдын, А. Методика исследования концепта «любовь» в русской и турецкой картинах мира (на материале произведений И.А. Бунина и Я.К. Беятлы). Наука і освіта. 2014. № 7. С. 7-10.

Белянин, В. Основы психолингвистической диагностики. Москва : Тривола, 2000. 248 c. 
Вертій, О. Розбудив українське єство. Нотатки про концертну подорож Віктора Мішалова «Шляхами кобзарів». Режим доступу: http://www.ukrcenter. com

Маслова, Г. Мифологизация художественного пространства и времени в творчестве. Вестник Новосибирского государственного педагогического университета. 2018. № 51. C. 162-176. DOI: 10.17223/19986645/51/13

Маковский, М. Лингвистическая генетика: Проблемы онтогенеза слова в индоевропейских языках. Москва : Издательство ЛКИ, 2007. 208 с.

Наливайко, С. Таємниці розкриває санскрит. Київ : Просвіта, 2000. 288 с.

Наливайко, С. Індоарійські таємниці України. Київ : Просвіта, 2004. 448 с.

Наливайко, С. Українська індоаріка. Київ : Євшан-зілля, 2007. 640 с.

Нудьга, Г. У колі світової культури. Львів : Львівський національний університет імені Івана Франка, 2006. 440 с.

Потебня, О. Мысль и языкъ. Харьковь : Типографія Адольфа Дарре, 1892. 228 с.

Сліпушко, О. Давньоукраїнський бестіарій (звірослов). Київ : Дніпро, 2001. 144 с.

Сорокин, Ю. Психолингвистические проблемы восприятия и оценки текста. Психолингвистические проблемы аспекты изучения текста. Москва, 1985. $167 \mathrm{c}$.

Сорокин, Ю. Этническая конфликтология (теоретические и экспериментальные фрагменты). Самара : Русский лицей, 1994. 94 с.

Українські народні думи. Том перший корпусу. Тексти №o 1-13 і вступ Катерини Грушевської. Харків, Державне видавництво України, 1927. 166 с.

Українські народні думи. Том другий корпусу. Тексти №№ 14-33 і вступ Катерини Грушевської. Харків; Київ : Пролетар, 1931. 304 с.

Черемський, К. Шлях звичаю. Харків : Глас, 2002. 445 с.

Черемський, К. Етномедичні аспекти практики українських традиційних співцівмузикантів. Традиційні музичні інструменти кобзарів $і$ лірників : Метеріали науково-практичної конференції з міжнародною участю (м. Київ, 2 червня 2017 р.) / Упоряд. К. Черемський; НЦНК «Музей Івана Гончара». Харків : Видавець Савчук Олександр, 2017. С. 168-193.

Bêrîtana. Режим доступу: http://kurtce-muzik.blogspot.com/2012/03/sipan-xelatberitan.html

Borden, J. (2016). Effects of national identity in transnational crises: Implications of social identity theory for attribution and crisis communications. International Journal of Communication, 10, 377-397.

Bubnova, I., \& Kazachenko, O. (2018). Dynamics of the Semantic Content of the Word Freedom. Psycholinguistics, 23(2), 11-24. https://doi.org/10.5281/zenodo.1199099 [in Russian, abstr. in English].

Dowell, Margaret-Mary Sulentic, \& Goering, Christian Z. (2018). Editors' introduction: On the promise and possibilities of arts integration in education. Pedagogies: An International Journal, 2. 85-91. DOI: 10.1080/1554480X.2018.1449180

Kim S., \& Sung, K.H. (2014). Revisiting the Effectiveness of Base Crisis Response Strategies in Comparison of Reputation Management Crisis Responses. Journal of Public Relations Research, 26, 62-78. DOI: 10.1080/1062726X.2013.795867

Thorne, S. (2016). Cultures-of-use and morphologies of communicative action. Language Learning \& Technology, 20(2), 185-191. Retrieved from http://lit.msu. edu/issues/june 2016/thorne.pdf

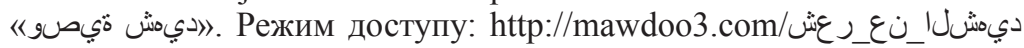


Українські народні думи: наиіональні особливості сприйняття...

\section{References}

Aidyn, A. (2014). Metodika issledovaniia kontsepta «liubov» v russkoi i turetskoi kartinakh mira (na materiale proizvedenii I.A. Bunina i Ia.K. Beiatly) [Methodology for the study of the concept of «love» in Russian and Turkish perception of the world (based on the works of I.A. Bunin and Ya.K. Beatli)]. Nauka i osvita - Science and Education, 7, 7-10 [in Russian].

Belianin, V. (2000). Osnovy psikholingvisticheskoi diagnostiki [Fundamentals of psycholinguistic diagnostics]. Moscow : Trivola [in Russian].

Beritana [Beritana]. Retrieved from http://kurtce-muzik.blogspot.com/2012/03/sipanxelat-beritan.html [in Kurdish].

Bubnova, I., \& Kazachenko, O. (2018). Dynamika smyslovoho zmistu znachennia slova svoboda [Dynamics of the meaning the word freedom]. Psycholinhvistyka Psycholinhuistics, 23(2), 11-24 [in Russian].

Borden, J. (2016). Effects of national identity in transnational crises: Implications of social identity theory for attribution and crisis communications. International Journal of Communication, 10, 377-397.

Vertii, O. (2013). Rozbudyv ukrainske yestvo. Notatky pro kontsertnu podorozh Viktora Mishalova «Shliakhamy kobzariv» [Woke up the Ukrainian nature. Notes about Victor Mishalov's concert tour «Kobzar Roads»]. Retrieved from: http://www. ukrcenter.com [in Ukrainian].

Kim, S., \& Sung, K.H. (2014). Revisiting the Effectiveness of Base Crisis Response Strategies in Comparison of Reputation Management Crisis Responses. Journal of Public Relations Research, 26, 62-78. DOI: 10.1080/1062726X.2013.795867

Dowell, Margaret-Mary Sulentic, \& Goering, Christian, Z. (2018). Editors' introduction: On the promise and possibilities of arts integration in education. Pedagogies: An International Journal, 2, 85-91. DOI: 10.1080/1554480X.2018.1449180

Maslova, G. (2018). Mifologizatsiia khudozhestvennogo prostranstva i vremeni $\mathrm{v}$ tvorchestve [Mythologization of art space and time in creativity]. Vestnik Tomskogo gosudarstvennogo universiteta. Filologiia - Bulletin of Tomsk State University. Philology, 51, 162-176 [in Russian]. DOI: 10.17223/19986645/51/13

Makovskii, M. (2007). Lingvisticheskaia genetika : Problemy ontogeneza slova $v$ indoevropeiskikh iazykakh [Linguistic genetics: Problems of word ontogeny in Indo-European languages]. Moscow : Izdatelstvo LKI [in Russian].

Nalyvaiko, S. (2000). Taiemnytsi rozkryvaie sanskryt [Mystery reveals Sanskrit]. Kyiv : Prosvita [in Ukrainian].

Nalyvaiko, S. (2004). Indoariiski taiemnytsi Ukrainy [Indo-Aryan secrets of Ukraine]. Kyiv : Prosvita [in Ukrainian].

Nalyvaiko, S. (2007). Ukrainska indoarika [Ukrainian Indo-ariotyk]. Kyiv : Yevshanzillia [in Ukrainian].

Nudha, H. (2006). U koli svitovoi kultury [In the circle of world culture]. Lviv : Lvivskyi natsionalnyi universytet imeni Ivana Franka [in Ukrainian].

Potebnia, O. (1892). Mysl i iazykie [Thought and language]. Kharkovie : Tipografiia Adolfa Darre [in Russian].

Slipushko, O. (2001). Davnoukrainskyi bestiarii (zviroslov) [Old Ukrainian bestiarius]. Kyiv : Dnipro [in Ukrainian].

Sorokin, Iu. (1985). Psikholingvisticheskie problemy vospriiatiia i otsenki teksta [Psikholingvisticheskie problemy aspekty izucheniia teksta], Psycholinguistic problems of perception and evaluation of the text - Psycholinguistic problems aspects of text study. Moscow [in Russian]. 
Ukrainian National Dumas: National Perceptions in the Process...

Sorokin, Iu. (1994). Etnicheskaia konfliktologiia (teoreticheskie $i$ eksperimentalnye fragmenty) [Ethnic Conflictology (Theoretical and Experimental Fragments)]. Samara : Russkii litsei [in Russian].

Thorne, S. (2016). Cultures-of-use and morphologies of communicative action. Language Learning \& Technology, 20(2), 185-191.

Hrushevska, K. (1927). Ukrainski narodni dumy [Ukrainian national dumas]. (Teksty №№ 1-13). Kharkiv: Derzhavne vydavnytstvo Ukrainy [in Ukrainian].

Hrushevska, K. (1931). Ukrainski narodni dumy [Ukrainian national dumas]. (Vols. 14-33). Kharkiv ; Kyiv : Proletar [in Ukrainian].

Cheremskyi, K. (2002). Shliakh zvychaiu [The path of custom]. Kharkiv : Hlas [in Ukrainian].

Cheremskyi, K. (2017). Etnomedychni aspekty praktyky ukrainskykh tradytsiinykh spivtsiv-muzykantiv [Ethnomedical practical aspects of the Ukrainian traditional music singers]. Proceedings from: Meterialy naukovo-praktychnoi konferentsii z mizhnarodnoiu uchastiu "Tradytsiini muzychni instrumenty kobzariv i lirnykiv» Methares of scientific and practical conference with international participation «Traditional musical instruments of kobzars and lyre artists». (pp. 168-193). Kharkiv : Vydavets Savchuk Olesandr [in Ukrainian].

Zapovid muchenyka. Retrieved from http://mawdoo3.com/2 ديهشا_نع_رع [in Arabic].

\section{АНОТАЦІЯ}

у статті наведено результати емпіричного дослідження етнопсихологічних груп людей, які проживають в різних регіонах України в контексті міжкультурних світоглядних систем. Зокрема, жителям України та іноземним студентам з країн Африки, Близького Сходу, які навчаються в Сумському державному університеті, було запропоновано поділитися враженнями від прослуханих дум у виконанні бандуриста В. Мішалова з Канади, який здійснив концертну подорож в Україні. Вони також переглянули та прослухали відеоаудіозаписи народних дум «Козак Голота», "Маруся Богуславка» у виконанні кобзаря М. Будника та бандуриста Ф. Жарка, проаналізували образи героїв, висловили своє розуміння і ставлення до їх дій і вчинків, зіставили з героями уснопоетичних творів своїх країн.

Розв'язуються проблеми, пов'язані із з'ясуванням національних особливостей світосприйняття українців, представників народів Аррики та Близького Сходу, виражених у їх мові, яка $\epsilon$ стрижнем народної психіки, мислення, своєрідністю морально-етичних норм життя етносу загалом. Також з'ясовано проблему сприйняття чужоземними студентами слова, ритму, музики, символічної системи народнопоетичних творів тощо. Зазначається, що психологічна навантаженість образної системи українських народних дум та народних пісень зазначених народів має суто начіональне забарвлення: вона $\epsilon$ категорією національного світогляду $і$ разом з тим $\epsilon \breve{~}$ категорією художньо-естетичною. 
Українські народні думи: національні особливості сприйняття...

Завдяки розв'язанню цих проблем сфрормовано чітке уявлення i розуміння тих чи інших складових національних характерів та національних картин світу в уснопоетичній творчості народів Африки, Близького Сходу та українських народних думах, що й становило основну мету дослідження та його новизну, адже такі типологічні зіставлення виконано вперше.

Результати проведених експериментальних досліджень, розвиток ідей думознавчих праць та досліджень національного характеру, особливостей національного світосприйняття, світорозуміння, світовираження та світоствердження розширили можливості глибшого і усебічнішого з'ясування призначення українських народних дум у формуванні та становленні національної особистості в процесі міжкультурного спілкування.

Ключові слова: дума, етнопсихологія, національні особливості сприйняття, світорозуміння, міжкультурне спілкування, національний характер, народна творчість.

\section{Набок Марина. Украинские народные думы: национальные особенности восприятия в процессе межкльтурного общения}

\section{АННОТАЦИЯ}

В статье приведены результаты эмпирического исследования этнопсихологических групп людей, проживающих в разных регионах Украины в контексте межкультурных мировоззренческих систем. В частности, жителям Украины и иностранным студентам из стран Афррики, Ближнего Востока, которые учатся в Сумском государственном университете, было предложено поделиться впечатлениями от прослушанных дум в исполнении бандуриста В. Мишалова из Канады, который совершил концертное путешествие по Украине. Они также просмотрели и прослушали видеоаудиозаписи народных дум «Казак Голота», "Маруся Богуславка» в исполнении кобзаря М. Будника и бандуриста Ф. Жарко, проанализировали образы героев, выразили своё понимание и отношение к их действиям и поступкам, сопоставили с героями уснопоетичних произведений своих народов.

Решаются проблемы, связанные с изучением национальных особенностей мировосприятия украинцев, народов Африки и Ближнего Востока, что определяется их язиком и является стержнем народной психики, мышления, своеобразием морально-этических норм жизни вцелом. Также решено проблему восприятия иностранными студентами слова, ритма, музыки, символической системы народных произведений. Отмечается, что психологическая насыщенность образной системы украинских народных дум и народных песен названных народов мира 
Ukrainian National Dumas: National Perceptions in the Process...

имеет сугубо национальную окраску: она является категорией национального мировоззрения и вместе с тем есть и категорией художественно-эстетической.

Благодаря решению этих проблем, сформировано чёткое представление и понимание тех или других составных национальных характеров и национальных картин мира в устнопоэтическом творчестве народов Африки, Ближнего Востока и украинских народных думах, что определило основную цель исследования и его новизну, поскольку такие типологические сопоставления выполнены впервые.

Результаты проведенных экспериментальных исследований, развитие идей думоведческих работ и исследований национального характера, особенностей национального мировосприятия, миропонимания, мировыражения и мироутверждения расширили возможности более глубокого изучения роли украинских народных дум в фрормировании и становлении национальной личности в процессе межкультурного общения.

Ключевые слова: дума, этнопсихология, национальные особенности восприятия, миропонимание, межкультурное общение, национальный характер, народное творчество. 